\title{
BOUNDEDNESS OF HARDY OPERATORS ON GENERALIZED AMALGAMS
}

\author{
PANKAJ JAIN AND SUKET KUMAR
}

Abstract. Boundedness of the Hardy operator $(T f)(x)=\int_{-\infty}^{x} f(t) d t$ between amalgam spaces $\ell^{q}\left(X_{u}\right)$ and $\ell^{\bar{q}}\left(L_{v}^{\bar{p}}\right)$ is obtained, where $X_{u}$ is a weighted Banach function space. The adjoint opertor $\left(T^{*} f\right)(x)=\int_{x}^{\infty} f(t) d t$ has also been treated.

Mathematics subject classification (2000): 26D10, 26D15.

Keywords and phrases: Hardy operator, amalgam spaces, Banach function space, Hardy inequality, adjoint Hardy operator.

\section{REFERENCES}

[1] C. BenNetT AND R. SHARPLEY, Interpolation of Operators, Academic Press, 1988.

[2] E. I. BEREZHNOI, Sharp estimates of operators on the cone of ideal spaces, Proc. Steklov Inst. Math., 3 (1994), 3-34.

[3] C. Carton-Lebrun, H. P. Heinig And S. C. Hofmann, Integral operators on weighted amalgams, Studia Math. 109 (1994) (2), 133-157.

[4] D. E. EDMUnds, P. GURKA AND L. PICK, Compactness of Hardy type integral operators in weighted Banach function spaces, Studia Math. 109 (1994), 73-90.

[5] P. JaIn, B. GuPTA AND D. Verma, Mean inequalities in certain Banach function spaces, J. Math. Anal. Appl., 334 (1) (2007), 358-367.

[6] P. JAIN, B. GUPTA AND D. VERMA, Hardy inequalities in certain Banach function spaces, Preprint.

[7] A. KufNer, L. MALigranda AND L.-E. PersSON, The Hardy Inequality - About its History and Some Related Results, Vydavetelsky Servis Publishing House, Pilsen, 2007.

[8] A. KufNer And L.-E. Persson, Weighted Inequalities of Hardy Type, World Scientific, New Jersey/London/Singapore/Hong Kong, 2003.

[9] E. LOMAKINA AND V. D. STEPANOV, On the Hardy type integral operators in Banach function spaces, Pub. Math. 42 (1998), 165-194.

[10] W. A. J. Luxemburg, Banach Function Spaces, Ph. D. Thesis, Delft Institute of Technology, Aseen (Netherland), 1955.

[11] L. Maligranda And L.-E. Persson, Generalized duality of some Banach function spaces, Nederl. Akad. Wetensch. Indag. Math. 51 (3) (1989), 323-338.

[12] V. MAZ’YA, Sobolev spaces, Springer-Verlag, Springer Series in Soviet Mathematics, 1985.

[13] B. OpIC And A. KufNer, Hardy-Type Inequalities, Pitman Research Notes in Mathematics Series, Longman Scientific \& Technical, Harlow, 1990.

[14] L.-E. PERSSON, Some elementary inequalities in connection with $X^{p}$-spaces, Constructive Theory of Functions (Varna 107), Publ. House Bulgar. Acad. Sci. Sofia, 1988, 367-376. 